\title{
A Case of Pleural Empyema Caused by Streptococcus pneumoniae Serotype19A in a Fully Vaccinated Child
}

\section{Tam Aşıı Bir Çocukta Streptococcus pneumoniae Serotip 19A'nın Neden Olduğu Bir Plevral Ampiyem Olgusu}

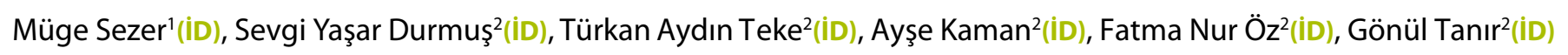 \\ ${ }^{1}$ Clinic of Pediatrics, Ankara Dr. Sami Ulus Maternity and Child Health and Diseases Training and Research Hospital, Ankara, Turkey \\ ${ }^{2}$ Clinic of Pediatric Infectious Diseases, Ankara Dr. Sami Ulus Maternity and Child Health and Diseases Training and Research Hospital, Ankara, Turkey
}

\begin{abstract}
Cite this article as: Sezer M, Yaşar Durmuş S, Aydın Teke T, Kaman A, Öz FN, Tanır G. Staphylococcal scalded skin syndrome in a child with acute lymphocytic leukemia.
\end{abstract} J Pediatr Inf 2019;13(4):e176-e179.

\section{Abstract}

Streptococcus pneumoniae is the most common cause of community acquired pneumonia and empyema in children. After the childhood 13-valent pneumococcal conjugate vaccination programs, the incidance of invasive pneumococcal disease with vaccine serotypes has been decreased. However pleural empyemas caused by vaccine serotypes were reported in fully and appropriately vaccineted cases. Here in, we presented a case of pleural empyema and lung abcess caused by S. pneumoniae serotype 19A, in an immunocompetent and fully vaccinated child with 13-valent pneumococcal conjugate vaccine.

Keywords: Pleural empyema, Streptococcus pneumoniae, vaccine

\section{Introduction}

Streptococcus pneumoniae is the most common agent of community-acquired pneumonia and empyema in children. Isolating S. pneumoniae from normally sterile body fluids like the blood, cerebrospinal fluid and pleural fluid is defined as invasive pneumococcal disease (IPD). With the development of pneumococcal conjugated vaccine (PCV), the incidence of IPD with virulent serotypes in the vaccine has decreased (1). Primarily, 7-valent PCV (PCV7) containing serotypes 4, 6B, 9V, 14, $18 \mathrm{C}, 19 \mathrm{~F}$, and $23 \mathrm{~F}$ was started to be administered in the United States of America in 2000. In addition to 7-valent PCV, 10-valent
Öz

Çocuklarda toplumdan kazanılmış pnömoni ve ampiyemin en sık etkeni Streptococcus pneumoniae'dır. Çocukluk dönemi 13-valanlı konjuge pnömokok aşı programları ile aşı suşlarının neden olduğu invaziv pnömokokal hastalık insidansı azalmıştır. Ancak uygun doz ve şekilde aşılanmış olmasına rağmen aşı suşu ile plevral ampiyem gelişen olgular bildirilmiştir. Biz de burada 13-valanlı konjuge pnömokok aşısı ile tam doz aşılı, bağışıklık sistemi sağlam bir çocukta S. pneumoniae serotip 19A'nın neden olduğu plevral ampiyem ve akciğer apsesi olgusu sunduk.

Anahtar Kelimeler: Plevral ampiyem, Streptococcus pneumoniae, aşı

PCV (PCV10) containing 1, 5, and 7F serotypes got license in Canada, Australia and Europe in 2008. Thirteen valent PCV included 3, 6A, and 19A serotypes in addition to PCV10, and obtained license from the European Drug Administration in 2009 (1). Thirteen valent pneumococcal conjugated vaccine (PCV13) was integrated to the expanded immunization program in Turkey in 2011, and vaccination rates reached $97 \%$ with PCV13 at the end of $2015(1,2)$. Based on the fact that 13-valent PCV contains more serotypes, it possesses a broader protection and safety in proportion to PCV7 (3). Nevertheless, fully vaccinated children developing empyema with the serotypes in the vaccine have been reported. Here, a case of pleural empyema and

Correspondence Address / Yazışma Adresi

\section{Sevgi Yasar Durmuş}

Ankara Dr. Sami Ulus Kadın Doğum Çocuk Sağlığı ve

Hastalıkları Eğitim ve Araştırma Hastanesi,

Çocuk Sağlığı ve Hastalıkları Kliniği,

Ankara-Türkiye

E-mail:drsvgysr@gmail.com

Received: 31.10 .2018 
pulmonary abscess developed with $S$. pneumoniae serotype $19 \mathrm{~A}$ in a immunocompetent, fully vaccinated child with PCV13 has presented.

\section{Case Report}

A previously healthy 3-year-8 months old female patient presented with complaints of malaise and cough lasting for 6 days and chest pain, respiratory distress, and tendency to sleep lasting for 3 days. Patient's medical history, and her familial history was unremarkable. The patient was vaccinated with 4 doses of PCV13 according to the routine vaccination schedule. On her physical examination, body temperature was $37.1^{\circ} \mathrm{C}$, respiratory rate was $100 / \mathrm{min}$, hearth rate was $150 / \mathrm{min}$, and oxygen saturation was $89 \%$. Breath sounds of the left hemithorax were significantly decreased her expiration was prolonged, and rhonchus, suprasternal and intercostal retractions were present. Laboratory findings were as follows; hemoglobin: $11.3 \mathrm{~g} /$ dL, white blood cell count: $16.990 / \mathrm{mm}^{3}$ (82\% neutrophil, $14 \%$ lymphocyte, 4\% monocyte), thrombocyte count: 340.000/ $\mathrm{mm}^{3}$, erythrocyte sedimentation rate (ESR) $99 \mathrm{~mm} / \mathrm{h}$, C-reactive protein (CRP): $270 \mathrm{mg} / \mathrm{dL}$. Posteroanteior chest radiography demonstrated consolidation on the middle zone of the right lung, disseminated consolidation and pleural effusion extending to the apex on the left lung (Figure 1). The depth of the pleural effusion monitored on the left lung on thoracic ultrasonography was measured as $10 \mathrm{~mm}$. Diagnostic thoracentesis was performed and $90 \mathrm{~mL}$ purulent fluid was aspirated. Gram staining of the pleural fluid showed plenty of polymorphonuclear leucocytes, but no bacteria. The patient was started on empirically intravenous ceftriaxone (100 mg/kg/day, 2 doses), vancomycin (60 mg/kg/day, 4 doses), clindamycin (40/mg/kg/ days, 4 doses) and oral oseltamivir $(2 \times 45 \mathrm{mg}$ ) since the patient admitted in the winter. The patient, who developed respiratory distress during follow up, was referred to the pediatric intensive care unit providing $\mathrm{O}_{2}$ support with high flow nasal cannula (HFNC). On admission day 2, closed-tube thoracostomy drainage was undertaken and due to the fact that there were intense septations in the pleural space, tissue plasminogen activator ( $t$ $\mathrm{PA})$ was given into the pleural space. Tube thoracostomy cathe- ter of the patient, who was given two doses of intrapleural t-PA and whose tube thoracostomy catheter was drained $470 \mathrm{~mL}$ of purulent fluid, was removed on admission day 9 due to the fluid drainage was terminated. While the blood culture of patient was negative, vancomycin-subceptible but penicillin, clindamycin and ceftriaxone-resistant $S$. pneumoniae was yielded on the pleural fluid culture of the patient. Clindamycin and oseltamivir treatment was terminated. The obtained isolate was typed/ identified as serotype 19 by swelling of the capsule (Quellung reaction) with commercial antiserum belonging to the Statens Serum Institute (Copenhagen, Denmark). On thoracic ultrasonography performed after the removal of tube thoracostomy of the patient, a $70 \times 37 \mathrm{~mm}$ in size solid formation, involving cystic-necrotic areas within, in the left lung was monitored. A thoracic computerized tomography (CT) was performed, and an appearance compatible with an abscess, approximately 80 x $55 \times 55 \mathrm{~mm}$ in size, with peripheral contrast involvement and levelling within in the left lung lower lobe was detected (Figure 2). The patient was consulted by the department of thoracic surgery and monitoring with antibiotic treatment was decided

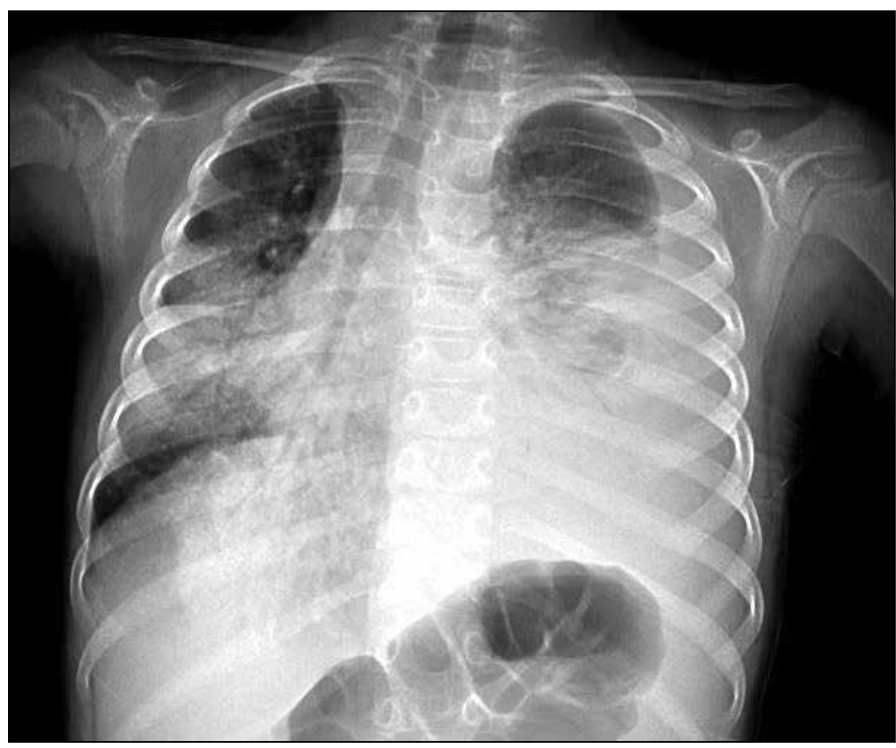

Figure 1. Consolidation in the right lung middle zone and in the left lung that extends to the apex, pleural effusion in the left lung.

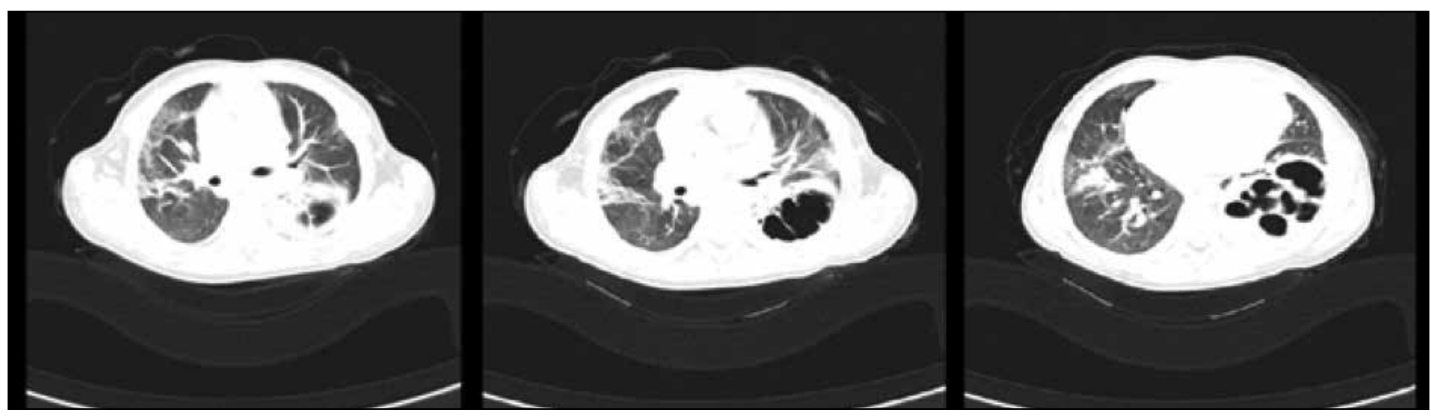

Figure 2. Atelectasis, infiltration areas in the form of frosted glass and subsegmental consolidation in the right lung; an appearance compatible with an abscess, approximately $80 \times 55 \times 55 \mathrm{~mm}$ in size, with peripheral contrast involvement and levelling within in the left lung lower lobe and atelectatic changes in the left lung. 
upon. Ceftriaxone treatment the patient was receiving was changed to meropenem on day 12 and vancomycin treatment was terminated on day 21. The abscess in the lower-mid zone of the left lung of the patient monitored with weekly thoracic ultrasonography was seen to have regressed to a size of $35 \times 22 \mathrm{~mm}$. Immunological evaluation demonstrated normal levels of total neutrophil and lymphocyte counts, serum IgG, IgA, IgM and IgE, lymphocyte subgroups and complement pathway. The patient did not have asplenia and HIV serology was negative. The patient, whose white blood cell count was $7280 / \mathrm{mm}^{3}$, ESR was $30 \mathrm{~mm} / \mathrm{h}$ and CRP was $3 \mathrm{mg} /$ $\mathrm{dL}$ in the tests performed on day 30 of meropenem treatment, was discharged with two doses of oral $7 \mathrm{mg} / \mathrm{kg}$ cefdinir treatment consecutively. In the tests done in the first month of polyclinic follow-up, patient's white blood cell count was $7900 / \mathrm{mm}^{3}$, ESR was $11 \mathrm{~mm} / \mathrm{h}$ and CRP was $3 \mathrm{mg} / \mathrm{dL}$, and cefdinir treatment was stopped due to the fact that the abscess of the patient distinctly regressed. On thoracic CT of the patient, whose outpatient follow-up continued for three months, the abscess was found to have regressed completely. Written informed consent was received from the patient's family in order for her medical information and imaging to be used in this study.

\section{Discussion}

A national, retrospective cohort study was conducted, in the United States of America after introduction of PCV7, to determine empyema incidence. Although empyema percentage related to pneumococcus decreased from $49 \%$ to $34 \%$, a significant alteration did not occur in the incidence of pneumococcus-related empyema and hospitalization rate was found as $0.7 / 100.000$ between the years 1997 and 2006. This increase in empyema despite the decrease in pneumococcus-related meningitis, bacteremia and pneumonia with 7-valent PCV has suggested that serotypes 1, 19A, 3 and 7, which are out of the coverage of this vaccine, are more frequently associated with empyema (5). In a study conducted in Canada comparing the incidence of invasive pneumococcal diseases in the pre-vaccination period, and post-PCV7 and post-PCV13 periods, it has been seen that post-vaccination hospitalization rates decreased from $17 / 100.000$ to $4 / 100.000$ and that age of admission with an invasive pneumococcal disease in the pre-vaccination period increased from 2 years of age to an average of 3.9 years after PCV13. It has been indicated that hospitalization after vaccination is much more related to focal infections (6). In a study carried out in our country, 156 children with empyema were analyzed in terms of S. pneumoniae serotypes irrespective of vaccination status, and S. pneumoniae has been detected as the agent in 53 (34\%). S. pneumoniae serotypes were identified in 33 patients and serotypes 1 and 5 were found to be the most frequently observed ones (1). Se- rotype 3-associated pleural empyema cases have been seen after PCV13 vaccination in Greece and serotypes 19A and 3 have been reported as the most dominant serotypes, 2-3 years after the introduction of vaccine (7). In 2016, necrotizing fasciitis and acute purulent pericarditis complicated with bronchopleural fistula, pneumothorax and subcutaneous empyema caused by S. pneumoniae serotype 19A in a 4-year-old fully vaccinated child was reported, and again in 2017, a case that developed pleural empyema due to serotype 19 was reported in a 2-year-old child from Casablanca $(8,9)$. In a study of 161 pediatric cases in the United Kingdom, vaccine failure was found to be $0.19 / 100.000$ in those vaccinated with PCV7; and $0.66 / 100.000$ in those vaccinated with PCV13 and it was reported that vaccine failure was rare, however bacteremic lower respiratory tract infection and empyema were more frequent with serotypes added to KPA13 compared to KPA7 serotypes (10). Vaccination failure is a state where the individual cannot produce antibodies against the vaccine after primary or booster doses. The causes of vaccination failure can be related to the patient, the vaccine or vaccination. Patient related causes can be arised from, due to immonudeficiency, being unable to produce antibody against vaccine itself, components or serotypes of the vaccine. Moreover, patient age, the presence or absence of nutrition deficiency, whether or not the patient was healthy at the time of vaccination, and whether or not the exposure to the pathogen before being vaccinated, effect the individual's response to the vaccine. Causes related to the vaccine itself are; first the vaccine does not include some serotypes and genotypes, second antigenic interaction and production stage related reasons. Vaccination-related causes are conditions such as mistakes made during vaccine administration, not conforming to cold chain during storage and transportation, and failure in following the vaccination schedule (4). Our case was fully vaccinated with PCV13 and 32 months had passed from the booster dose. Immunodeficiency examinations of our case, for whom a sufficient amount of time had passed for the protective immunological response to develop, was normal and IgG titer against pneumococcus was at a protective level. Up-to-date treatment approach to pleural empyema and pulmonary abscess is tube thoracostomy and underwater seal drainage in addition to antibiotic therapy. Recovery frequency of the cases with pulmonary abscess with medical treatment without a sequel has been reported as $70 \%-90 \%$, and thus, open surgery that has a high rate of mortality is preferred in a very limited number of cases (11). Our case was successfully treated with tube thoracostomy and underwater seal drainage together with antibiotic treatment.

In conclusion, parapneumonic pleural empyema may develop with the serotypes within the vaccine in immunocompetent individuals fully vaccinated with PCV13. Therefore, even though national vaccination schedulde includes PCV13, 
monitoring the surveillance of invasive pneumococcal diseases and defining agent serotypes have importance.

Informed Consent: Written consent was obtained.

Peer-review: Externally peer-reviewed.

Author Contributions: Concept - SYD, TAT; Design - MS, FNÖ, AK; Supervision - TAT, GT; Data Collection and/or Processing - MS, SYD; Analysis - GT, FNÖ, TAT; Literature Review - MS, SYD, AK; Writing - MS, SYD, TAT; Critical Review - FNÖ, GT, AK.

Conflict of Interest: The authors have not reported a conflict of interest.

Financial Disclosure: There is no financial support.

\section{References}

1. Ceyhan M, Ozsurekci Y, Gürler N, Ozkan S, Sensoy G, Belet N, et al. Distribution of Streptococcus pneumoniae serotypes that cause parapneumonic empyema in Turkey. Clin Vaccine Immunol 2013;20:972-6!"[CrossRef]'

2. http://www.saglikistatistikleri.gov.tr/dosyalar/SIY_2015.pdf [CrossReff]"

3. Yeh SH, Gurtman A, Hurley DC, Block SL, Schwartz RH, Patterson $S$, et al; 004 Study Group.. Immunogenicity and safety of 13-valent pneumococcal conjugate vaccine in infants and toddlers. Pediatrics 2010;126:493-505. [CrossReff]

4. Heininger U, Bachtiar NS, Bahri P, Dana A, Dodoo A, Gidudu J, et al. The concept of vaccination failure. Vaccine 2012;30:1265-8. [CrossReff]"
5. Bernaola E, Gil F, Herranz M, Gil-Setas A, Guevara M, Castilla J. Pneumococcal vaccination and pneumonia associated with pleural effusion in a pediatric population. Pediatr Infect Dis J 2018;37:87-92. [CrossRef],

6. Ricketson LJ, Conradi NG, Vanderkooi OG, Kellner JD. Changes in the nature and severity of invasive pneumococcal disease in children before and after the seven-valent and thirteen valent pneumococcal conjugate vaccine programs in Calgary, Canada. Pediatr Infect Dis J 2018;37:22-7. [CrossRef]

7. Madhi F, Godot C, Bidet P, Bahuaud M, Epaud R, Cohen R. Serotype 3 pneumococcal pleural empyema in an immunocompetent child after 13-valent pneumococcal conjugate vaccine. Pediatr Infect Dis J 2014;33:545-6. [CrossRef

8. Lu S, Tsai JD, Tsao TF, Liao PF, Sheu JN. Necrotizing pneumonia and acute purulent pericarditis caused by Streptococcus pneumoniae serotype 19A in a healthy 4-year-old girl after one catch-up dose of 13-valent pneumococcal conjugate vaccine. Paediatr Int Child Health 2016;29:1-5. [CrossRef]

9. Diawara I, Zerouali K, Elmdaghri N, Abid A. A case report of parapneumonic pleural effusion caused by Streptococcus pneumoniae serotype $19 \mathrm{~A}$ in a child immunized with 13-valent conjugate pneumococcal vaccine. BMC Pediatr 2017;17:114. [CrossRef]"

10. Oligbu G, Collins S, Andrews N, Sheppard CL, Fry NK, Slack MPE, et al. Characteristics and serotype distribution of childhood cases of invasive pneumococcal disease following pneumococcal conjugate vaccination in England and Wales, 2006-2014. Clin Infect Dis 2017;65:1191-8. [CrossRef]"

11. Loizzi M, De Palma A, Pagliarulo V, Loizzi D, Sollitto F. Pulmonary infections of surgical interest in childhood. Thorac Surg Clin 2012;22:387-401. [CrossRef]" 